ISSN 0206-5657. Вісник Львівського університету. Серія біологічна. 2019. Випуск 80. С. 177-182 Visnyk of the Lviv University. Series Biology. 2019. Issue 80. P. 177-182

УДК 577.35:576.33 https://doi.org/10.30970/vlubs.2019.80.19

\title{
Са $^{2+}$-МОБІЛІЗАЦІЯ У ГЛАДЕНЬКИХ МІОЦИТАХ СЕЧОВОГО МІХУРА ЩУРА У ВІДПОВІДЬ НА ПРИКЛАДАННЯ КАПСАӤЦИНУ
}

\author{
Б. Шаропов*, Ю. Дискіна, С. Сльяшов, А. Алєксєєва \\ Інститут фізіології імені О.О. Богомольия НАН України \\ вул. Богомольия, 4, Київ 01024, Україна \\ e-mail: sharopov@biph.kiev.ua
}

Згідно з даними, зібраними у попередніх дослідженнях термочутливого іонного каналу TRPV1, в організмі він відіграє не лише канонічну роль сенсора опікової температури $\left(>42{ }^{\circ} \mathrm{C}\right)$ в аферентних волокнах шкіри, але і полімодального рецептора, залученого в інші численні процеси завдяки проникності його селективної пори до іонів $\mathrm{Ca}^{2+}$. Деякі дослідницькі групи раніше представили непрямі імунохімічні та молекулярно-генетичні свідчення щодо наявності цього іонного каналу в гладеньких міоцитах сечового міхура, проте функціональних даних наведено не було. У запропонованій статті досліджено вплив капсаїцину (КАПС), агоніста TRPV1 й активної речовини $з$ плодів гострого червоного перцю з роду Capsicum, на трансмембранні струми та кальцієве сигналювання гладеньком'язових клітин (ГМК) сечового міхура щура. Прикладання КАПС у насичувальній концентрації 10 мкМ не викликало жодних змін у трансмембранних струмах через плазмалему ГМК, зареєстрованих методом patch clamp у конфігурації «ціла клітина», що свідчить про відсутність TRPV1 у плазматичній мембрані цих клітин. Разом з тим, аплікація капсаїцину спричиняла TRPV1-опосередковані ефекти в нейронах дорсальних корінцевих гангліїв (ДКГ), що слугувало позитивним контролем. 3 іншого боку, аплікація цього фармакологічного агента викликала виражену $\mathrm{Ca}^{2+}$-відповідь у експерименті з кальцієвої візуалізації за допомогою $\mathrm{Ca}^{2+}$-чутливого флуоресцентного барвника Fura-2 AM у 42 \% досліджених ГМК. Водночас у решті клітин кальцієвий сигнал у відповідь на КАПС не спостерігали, хоча їхню життєздатність було підтверджено аплікацією контрольного активатора холінорецепторів карбахолу (КХ) в концентрації 100 мкМ. Таким чином, представлені дані можуть свідчити про раніше не відому експресію TRPV1 у частині ГМК та його субклітинну локалізацію у саркоплазматичному ретикулумі цих клітин.

Ключові слова: TRPV1, сечовий міхур, гладеньком'язова клітина

Хоча сечовий міхур (CM) з його на позір простою функцією накопичення й виведення сечі вважається відносно повно дослідженим вісцеральним органом, питання про тонкі молекулярні механізми його роботи є досі контроверсійним [5]. Згідно з канонічною моделлю, детрузор - гладенький м'яз, що є частиною стінки СМ і забезпечує його скоротливу активність - здійснює механічну роботу під час сечовиділення у відповідь на виділення ацетилхоліну (ACh) з парасимпатичних нервових волокон [4]. Цей нейротрансмітер, зв'язуючись із холінорецептором типу $\mathrm{M}_{3}$ та, згідно з деякими роботами, частково і $\mathrm{M}_{2}$, викликає збільшення концентрації іонів $\mathrm{Ca}^{2+}$ у цитозолі, чим активує актин-міозиновий скоротливий апарат $[4,5]$.

Проте дані щодо послідовності подій між активацією метаботропного рецептоpa AChR та збільшенням цитозольної концентрації $\mathrm{Ca}^{2+} \epsilon$ суперечливими. Деякі автори отримали свідчення на користь того, що в гладеньком'язовій клітині (ГМК) детрузора при активації холінорецептора $\mathrm{M}_{3}$ активується канонічний для цього класу GPCR сигнальний шлях, який включає фосфоліпазу C (PLC), синтез інозитолтрифосфату (IP3), активацію

(C) Шаропов Б., Дискіна Ю., Сльяшов С., Алєксєєва А., 2019 
IP3-рецептора й вивільнення через останній іонів $\mathrm{Ca}^{2+}$, депонованих у саркоплазматичному ретикулумі [1]. 3 іншого боку, кількома групами було показано, що блокування PLC не призводить до суттєвого зниження сили скорочення детрузора, викликаного активацією AChR [7]. Більше того, активація мускаринових холінорецепторів у CM, окрім депо-залежного виходу $\mathrm{Ca}^{2+}$, може викликати трансмембранний неселективний катіонний струм $\left(\mathrm{mI}_{\mathrm{CAT}}\right)$, який опосередковується через два різних іонних канали не відомої досі природи, що теж може слугувати джерелом кальцію для активації скорочення [10]. Таким чином, послідовність молекулярних подій після активації $\mathrm{M}_{3}$-холінорецептора й до активації актин-міозинового скоротливого апарату потребує уточнення, що може стати у пригоді під час розробки новітніх фармакологічних інструментів для корекції дисфункції СМ різної етіології [11].

Раніше низкою дослідницьких груп, що використовували методи імуногістохімії та ПЛР зі зворотною транскрипцією, були отримані свідчення на користь експресії у ГМК детрузора іонного каналу TRPV1 [2,9]. Цей білок $є$ полімодальним неселективним катіонним каналом, що може активуватися широким спектром подразників, найбільш канонічними 3 яких $\epsilon$ висока температура $\left(>43^{\circ} \mathrm{C}\right)$ й активна речовина з плодів гострого червоного перцю з роду Capsicum - капсаїцин [3]. У запропонованій статті ми демонструємо відсутність відповіді ГМК на аплікацію його агоніста капсаїцину (КАПС) в експериментах patch clamp, що свідчить про відсутність TRPV1 у плазмалемі ГМК. Водночас, ми наводимо докази на користь локалізації цього іонного каналу у внутрішньоклітинних $\mathrm{Ca}^{2+}$-депо в щонайменше 42 \% ГМК методом кальцієвої візуалізації.

\section{Матеріали та методи}

Виділення гладеньком'язових клітин (ГМК) детрузора. Для цього дослідження було використано 18 щурів лінії Вістар, самців віком 3 міс. і масою тіла 200-250 г. Усі експериментальні процедури проводили у відповідності до Директиви СС 2010/63/EU «Стосовно захисту тварин, що використовуються у наукових цілях» і вказівок інститутського біотичного комітету. Тварини утримували у віварії Інституту фізіології ім. Богомольця на стандартному кормі й водогінній воді, доступ до яких мали ad libitum. Щурів присипляли шляхом інгаляції $\mathrm{CO}_{2}$ й декапітували, після чого їхні сечові міхури ізолювали і поміщали у безкальцієвий, охолоджений до $4{ }^{\circ} \mathrm{C}$ фізіологічний розчин такого складу (у мM): $\mathrm{NaCl}-80$, глутамат - 40, $\mathrm{KCl}$ - 5, HEPES - 10, глюкоза - 5 ( $\mathrm{pH} 7,4$ за допомогою $\mathrm{NaOH}$ ). Після цього СМ додатково очищували від сполучних тканин і уротелію, нарізали з нього шматки завбільшки 0,5-1 мм й піддавали їх ферментативній обробці папаїном (1 мг/мл) за наявності відновного реагента дитіотреїтолу (DTT, 1 мг/мл) та бичачого сироваткового альбуміну (БСА, 1 мг/мл) упродовж 25 хв за $37^{\circ} \mathrm{C}$. Тканину відмивали від ензимів центрифугуванням при $200 \mathrm{~g}$ упродовж 4 хв із подальшим зливанням супернатанта й заміною його на свіжий розчин, після чого піддавали іiі ферментативній обробці колагеназою II (0,5 мг/мл) за наявності інгібітора трипсину (0,5 мг/мл) і БСА (1 мг/мл) упродовж 20 хв за $37{ }^{\circ} \mathrm{C}$. Після відмивання ензиму ізольовані ГМК отримували шляхом диспергування тканини піпеткою Пастера. Усі реагенти, якщо не зазначено протилежне, були придбані в Sigma, США.

Реєстрація $\mathrm{Ca}^{2+}$-сигналу. Гостроізольовані ГМК висаджували на круглі покривні скельця, вкриті полі-L-лізином для кращої адгезії, та заливали розчином Тіроде такого складу (у мМ): $\mathrm{NaCl}-135, \mathrm{KCl}-5, \mathrm{CaCl}_{2}-2, \mathrm{MgCl}_{2}-1$, HEPES - 10, глюкоза - 5 (pH 7,4 за допомогою $\mathrm{NaOH}$ ). Клітини навантажували $\mathrm{Ca}^{2+}$-чутливим барвником Mag-Fluo-4AM (Molecular Probes, США) у концентрації $5 \mu \mathrm{M} /$ л протягом 25 хв, після чого ретельно відмивали його, тричі замінюючи розчин Тіроде на свіжий. Реєстрацію інфлюксів $\mathrm{Ca}^{2+}$ проводи- 
ли за допомогою флуоресцентної конфокальної системи LSM 5 PASCAL (Zeiss, Німеччина), збуджуючи флуоресценцію барвника хвилею 488 нм і записуючи відповідь на 510 нм. Задля активації TRPV1 використовували капсаїцин (10 мкM, маточний розчин у етиловому спирті - 10 мМ), а для перевірки життєздатності клітин - карбахол (10 мМ).

Електрофізіологічні вимірювання. Клітини пасивно осаджували у пластикових чашках Петрі протягом 10-15 хв і заливали розчином Тіроде. Інтегральні трансмембранні струми записували за допомогою установки patch-clamp із підсилювачем PC-ONE (Dagan Instruments, США) і програмним забезпеченням pClamp 8.0 (Axon Instruments, CША). Miкропіпетки з боросилікатного скла (WPI, США) з опором 3-5 M $\Omega$ виготовляли на пулері P-97 (Sutter Instrument, США), оплавляли й заповнювали внутрішньоклітинним розчином такого складу (у мМ): $\mathrm{KCl}-20$, К-глюконат - 108, EGTA - 8, $\mathrm{CaCl}_{2}-4, \mathrm{MgCl}_{2}-1, \mathrm{Mg}$ ATP - 1, HEPES - 10 (pH 7,4 за допомогою $\mathrm{KOH}$ ). Запис струмів проводили за протоколом типу «епізодична стимуляція» за стаціонарних значень командного потенціалу $\left(\mathrm{V}_{\text {comm }}\right)$, фіксованих на +50 мВ і -100 мВ протягом 100 мс, розділених рамповим періодом тривалістю 100 мс; окремі епізоди стимуляції були відокремлені відновними інтервалами тривалістю 2 c, за яких мембранний потенціал підтримувався на -60 мВ. Для активації TRPV1 до клітин прикладали капсаїцин (10 мкM). Як позитивний контроль наявності TRPV1 використовували нейрони дорсальних корінцевих гангліїв (ДКГ), протокол виділення яких доступний у інших роботах [8].

\section{Результати і їхнс обговорення}

У численних роботах, присвячених першій із відкритих функцій іонного каналу TRPV1 як рецептора опікової температури в нейронах дорзальних корінцевих гангліїв (ДКГ), методом patch-clamp було показано його локалізацію у плазматичній мембрані цих клітин [3]. Для дослідження експресії TRPV1 у ГМК детрузора ми спершу використали аналогічний підхід. У електрофізіологічних експериментах у конфігурації «ціла клітина» ГМК у відповідь на стимуляцію різними значеннями $\mathrm{V}_{\text {comm }}$ виявили відносно слабкі трансмембранні струми на стаціонарному $\mathrm{V}_{\text {сотm }}$ як -100 мB $(-19 \pm 2$ пA, n=28), так і на +50 мB $(213 \pm 32$ пA, $\mathrm{n}=28)$, що, ймовірно, опосередковувалися фоновими $\mathrm{K}^{+}$-каналами 3 родини 2PK (рис. 1, А). Крім того, на значеннях $\mathrm{V}_{\text {comm }}+50$ спостерігали шумоподібні флуктуації $\mathrm{I}_{\mathrm{m}}$ з амплітудою в межах 12-45 пА, характерні для $\mathrm{K}^{+}$-каналів високої провідності (ВК, дані не представлено). На рамповій фазі електрофізіологічного протоколу близько до $\mathrm{V}_{\text {comm }}-30 \mathrm{mB}$ спостерігали вхідний струм, ймовірно, опосередкований $\mathrm{Ca}^{2+}$-каналами (рис. $\left.1, \mathrm{~A}\right)$. Однак після аплікації активатора TRPV1, капсаїцину, у концентрації насичення 10 мкМ жодного ефекту не спостерігали (рис. 1, А). Для позитивного контролю отриманих результатів робочий розчин КАПС і експериментальні умови, використані в дослідах на ГМК, були також верифіковані на нейронах ДКГ. Прикладання КАПС викликало виражений трансмемб-

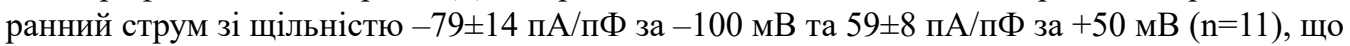
свідчить про активацію TRPV1 (рис. 1, Б). Таким чином, наші дані свідчать про відсутність іонного каналу TRPV1 у плазматичних мембранах ГМК.

Втім, відсутність $\mathrm{I}_{\mathrm{TRPV} 1}$ у електрофізіологічних експериментах не є доказом його відсутності в клітині загалом, оскільки метод patch-clamp дає змогу спостерігати лише струми, що проходять крізь плазматичну мембрану. У роботі Lotteau зі співавт. на прикладі міофібрил посмугованих м'язів показано, що TRPV1 може локалізуватись у мембранах внутрішньоклітинних органел, таких як саркоплазматичний ретикулум (CP) $[6,12]$. Щоб перевірити можливу наявність цього іонного каналу у внутрішніх $\mathrm{Ca}^{2+}$-депо ГМК, ми використали метод кальцієвої візуалізації. Аплікація 10 мкМ КАПС до деяких (n=14) гостроізольованих міоцитів детрузора викликала виражене збільшення $\left[\mathrm{Ca}^{2+}\right]_{\text {вн }}$, що свідчить про 
наявність у їхніх CP TRPV1 (рис. 2, А). Проте в інших ГМК (n=19) рівень флуоресценції після прикладання КАПС лишався незмінним упродовж усього часу аплікації (рис. 2, Б). Оскільки відсутність $\mathrm{Ca}^{2+}$-сигналу за наявності активатора може бути пов'язана $з$ порушеннями у фізіології ГМК в процесі виділення, для перевірки їхньої життєздатності використали карбахол (KX, 10 мМ), синтетичний аналог ацетилхоліну. Аплікація КХ викликала швидку, пікоподібну відповідь як у клітинах, що відповідали на КАПС, так і в решті ГМК (дані не представлено). Отже, наші дані свідчать про те, що гладенькі міоцити детрузора лише частково експресують TRPV1 (44%), який локалізований у CP.
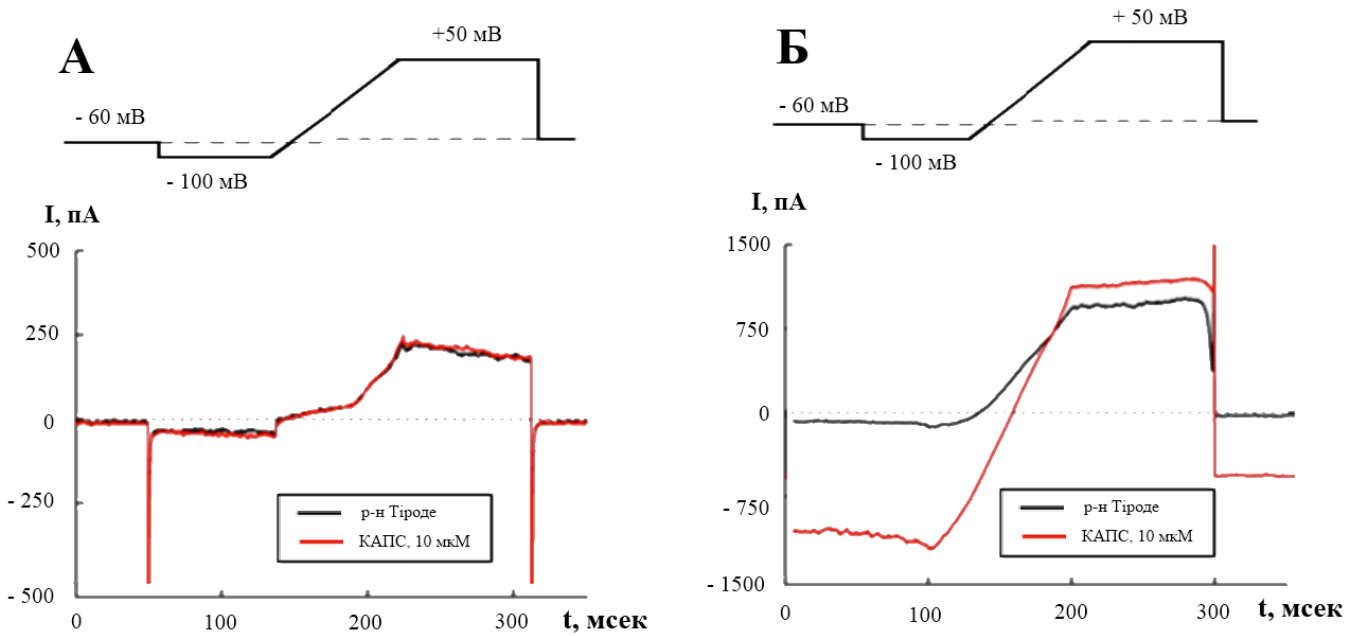

Рис. 1. Репрезентативні електрофізіологічні вимірювання $\mathrm{I}_{\mathrm{TRPV} 1}$ у ГМК (А) та нейронах ДКГ (Б). Активацію TRPV1 проводили за допомогою 10 мкМ розчину КАПС. Трансмембранні струми у клітинах за всіх значень $\mathrm{V}_{\text {comm }}$ не змінювались у разі ГМК, що свідчить про відсутність TRPV1 у їхніх плазматичних мембранах

A
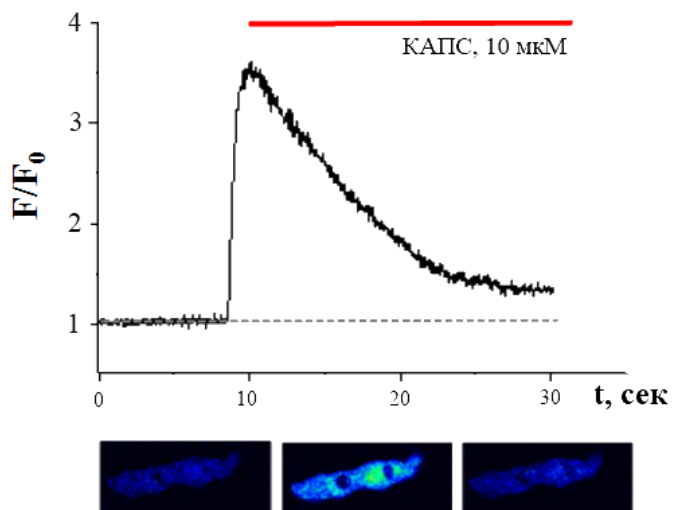

Б

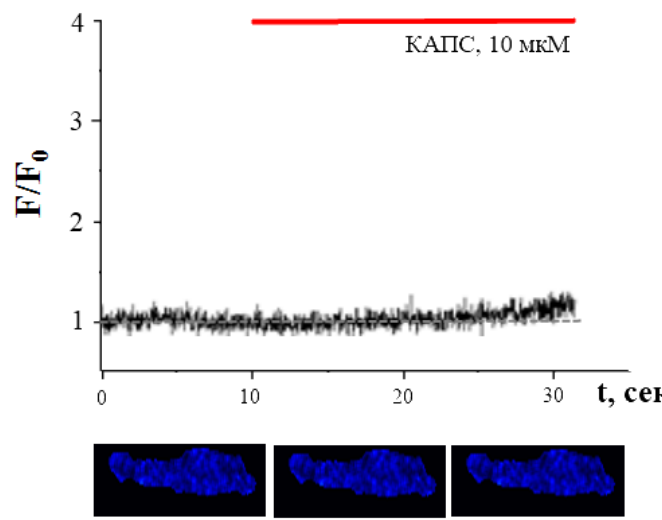

Рис. 2. Репрезентативні записи $\mathrm{Ca}^{2+}$-залежної флуоресценції у ГМК після аплікації 10 мкМ розчину КАПС: А - клітини, що відповіли на стимуляцію (n=14); Б - клітини, що лишилися неактивованими $(\mathrm{n}=19)$

Таким чином, у цій роботі ми наводимо експериментальні свідчення на користь того, що TRPV1 немає у плазматичній мембрані ГМК детрузора, проте $є$ у внутрішньоклітин- 
них $\mathrm{Ca}^{2+}$-депо 42 \% цих клітин. Необхідно зауважити, що така непостійна експресія цього білка не зменшує його фізіологічної значущості, позаяк міоцити СМ поєднані щілинними контактами, утворюють функціональний синцитій і здатні проводити $\mathrm{Ca}^{2+}$-хвилі [4]. Вивільнюючи кальцій із внутрішньоклітинних депо, TRPV1 може впливати на скоротливу активність цих клітин. Хоча з наших даних неможливо виснувати, якими саме факторами цей іонний канал активується у ГМК, можна припустити, що 3-поміж усіх потенційних його активаторів, зважаючи на постійність температури та $\mathrm{pH}$ у цитозолі, найбільш імовірними фізіологічними агоністами TRPV1 у детрузорі є сигнальні ліпіди, зокрема, похідні арахідонової кислоти. 3'ясування цього питання потребує проведення подальших досліджень.

\section{СПИСОК ВИКОРИСТАНОЇ ЛІТЕРАТУРИ}

1. An J. Y., Yun H. S., Lee Y. P. et al. The intracellular pathway of the acetylcholine-induced contraction in cat detrusor muscle cells // Brit. J. Pharmacol. 2002. Vol. 137. P. 1001-1010.

2. Avelino A., Cruz F. TRPV1 (vanilloid receptor) in the urinary tract: expression, function and clinical applications // N-S Arch. Pharmacol. 2006. Vol. 373. P. 287-299.

3. Caterina M. J., Schumacher M. A., Tominaga M. et al. The capsaicin receptor: a heat-activated ion channel in the pain pathway // Nature. 1997. Vol. 389. P. 816-824.

4. de Groat W.C., Griffiths D., Yoshimura N. Neural control of the lower urinary tract // Compr. Physiol. 2015. Vol. 5. P. 327-396.

5. Fry C. H., Meng E., Young J. S. The physiological function of lower urinary tract smooth muscle // Auton. Neurosci.: basic \& clinical. 2010. Vol. 154. P. 3-13.

6. Lotteau S., Ducreux S., Romestaing C. et al. Characterization of functional TRPV1 channels in the sarcoplasmic reticulum of mouse skeletal muscle // PloS one. 2013. Vol. 8. P. e58673.

7. Schneider T., Fetscher C., Krege S., Michel M. C. Signal transduction underlying carbacholinduced contraction of human urinary bladder // J. Pharmacol. Exp. Ther. 2004. Vol. 309. P. 1148-1153.

8. Sharopov B. R., Gulak K. L., Philyppov I. B. et al. TRPV1 alterations in urinary bladder dysfunction in a rat model of STZ-induced diabetes // Life Sciences. 2018. Vol. 193. P. 207-213.

9. Stein R. J., Santos S., Nagatomi J. et al. Cool (TRPM8) and hot (TRPV1) receptors in the bladder and male genital tract // J. Urology. 2004. Vol. 172. P. 1175-1178.

10. Yamamoto M., Unno T., Matsuyama $H$. et al. Two types of cation channel activated by stimulation of muscarinic receptors in guinea-pig urinary bladder smooth muscle // J. Pharmacol. Sci. 2008. Vol. 108. P. 248-257.

11. Yoshimura N., Ogawa T., Miyazato M. et al. Neural mechanisms underlying lower urinary tract dysfunction // Korean J. Urology. 2014. Vol. 55. P. 81-90.

12. Zhao R., Tsang S. Y. Versatile roles of intracellularly located TRPV1 channel // J. Cellular Physiology. 2017. Vol. 232. P. 1957-1965.

Стаття: надійшла до редакиії 11.10.18

доопрачьована 19.02.19

прийнята до друку 21.02.19 


\title{
$\mathrm{Ca}^{2+}$ MOBILIZATION IN THE SMOOTH MYOCYTES OF THE RAT URINARY BLADDER INDUCED BY CAPSAICIN APPLICATION
}

\author{
B. Sharopov, Iu. Dyskina, S. Yelashov, A. Alexeeva
}

\author{
Department of Nerve \& Muscle Physiology \\ Bogomoletz Institute of Physiology, NAS of Ukraine \\ 4, Bogomotetz St., Kyiv 01024, Ukraine \\ e-mail:sharopov@biph.kiev.ua
}

According to the previous studies of the heat-activated TRPV1 ion channel, in the organism it could play not only the canonical role of the nociceptive temperature sensor (activation threshold $>42{ }^{\circ} \mathrm{C}$ ) but also be a polymodal receptor involved in numerous other processes due to the permeability of its selective pore for $\mathrm{Ca}^{2+}$ ions. Prior studies conducted by other research groups provided indirect evidence obtained with immunochemistry and PCR approaches suggesting the presence of this ion channel in the smooth muscle cells (BSM) of the urinary bladder though the functional data is still absent. In this study we investigated the effect of capsaicin (CAP), a pungent component of hot chili pepper and an agonist of TRPV1, on the transmembrane currents and the $\mathrm{Ca}^{2+}$ signaling of the bladder smooth muscle cells of the rat. CAP at the saturating concentration of $10 \mu \mathrm{M}$ had no influence on the transmembrane currents of BSMs registered with the whole-cell patch clamp technique which suggests the absence of TRPV1 in the plasma membrane of these cells. Along with this negative data the control electrophysiological recordings on the dorsal root ganglion (DRG) neurons was conducted showing the presence of CAPS-evoked currents in this cells. On the opposite, the application of this pharmacological agent induced the apparent $\mathrm{Ca}^{2+}$ response in calcium imaging experiments with the $\mathrm{Ca}^{2+}$-sensitive fluorescent dye Fluo-4 AM in $42 \%$ of the BSMs examined. At the same time, the rest of these cells showed no calcium influx though their viability was validated with control cholinoreceptor agonist, carbachol $(\mathrm{CCh})$, in the concentration of $100 \mu \mathrm{M}$. Therefore, our findings suggest the previously unreported expression of TRPV1 in the part of the BSMs and its subcellular localization in the sarcoplasmic reticulum of these cells.

Keywords: TRPV1, urinary bladder, smooth muscle cell 